\title{
Impact on Social Networking Sites Among the Women Undergraduate Students
}

\author{
Deepthy K, D. Shalini
}

\begin{abstract}
The study has been used to explore the impact of social networking sites amongst the undergraduate women students. In the framework of existing digital media, social networking sites have been known as individuals, by means of the Internet and web application to converse in previously unfeasible ways. It can be predominantly effect of a culture-wide impression shift in the uses and potential of the internet itself. The objectives of the study are to ascertain the different type of social networking sites used by women undergraduate students to scrutinize the level of usage, reason of using social networking sites, to settle on the advantages of using social networking sites and to make out the dangers associated with social networking and to submit strategies to restructure such dangers. The descriptive design has been in use to get responses from a sample size of 115 women undergraduate students who were selected via random sampling techniques. The 115 respondents completed and returned the questionnaire precisely indicating $100 \%$ response rate. The outcome of the study discloses that all the women undergraduate students uses social networking sites to expand information, interaction with friends, connecting to their classmates for online study, discussing serious national issues and watching movies etc. There are many advantages of using social networking sites and their menaces combined with social networking and such dangers can be restructured using the strategies available in the work. From the findings, it was recommended that women undergraduate students should attend various awareness program to update on the negative aspects of social networking sites etc. Based on the findings suitable suggestions were also made.
\end{abstract}

\section{INTRODUCTION}

Social networking sites in the digital world are rapidly becoming admired as both interpersonal and public communication for women undergraduate students. The use of internet-based social media programs is to make connections with friends, family, classmates, customers and clients. Social networking in the digital field is used for special as well as business purposes. The programs show the relationships between individuals and facilitate the acquisition of new contacts. Examples of Social Networking Sites include Facebook, Whats app, Twitter, etc. There has been major interest and concern about the risks of digital media online social networking because of access to personal information and the anonymity that the system allows. Social networking sites are contemporary interactive communication paths in digital era through which people bond to one another, share ideas, experiences, pictures, messages and information of interest. Furthermore, as a

Revised Manuscript Received on September 10, 2019.

Deepthy K, Assistant Professor- Department of Business Administration, Sri Ramakrishna College of Arts \& Science for Women, Tamil Nadu, India.

(Email.Id - deepthymgt@srcw.ac.in)

D. Shalini, Assistant Professor- Department of Business Administration, Sri Ramakrishna College of Arts \& Science for Women, Tamil Nadu, India.

(Email.Id - shalinimgt@srcw.ac.in) novel phenomenon, it is necessary to examine how women undergraduate students use the new means of communication in the digital world. This is because women student's contribution as young generation can make or transform any nation. The new communication technology in the digital era is one of few ways that young women's can bypass the inefficiencies in the system that allow the status quo to hold on. It lowers the entire barriers to entry for everyone to get involved and be heard. A study like this shall help to ascertain whether women undergraduate students' use of the media could be regulated or not.

\section{LITERATURE REVIEW}

Bharadwaj (2017) studied the extensive use of Social Networking in India among the youth. The study attempted to investigate the extent of social networking impact on the Indian youth. The study is done among the youth as the course of a country and culture is chosen by the direction taken by youths of that country. This paper analysed the pattern of social networking usage and impact in order to determine the social networking addiction.

Subramani (2015) analysed the academic usage of social networking sites among university students in Tamil Nadu. By using the survey method, the study attempted to study how university students across state universities of Tamil $\mathrm{Nadu}$ use social media for academic purposes. A sample size of 282 M.Phil, Doctoral and master's students were considered for the study. The study revealed a reservedly behaviour of students in using the various digital and social media platforms. The study suggested a need to spread the potential of social media through separate curriculum and adding the fun element in learning.

Khurana (2015) studied level of awareness among the youth social networking sites such as Facebook, My Space, Twitter, LinkedIn, Skype etc are a few such sites that attract maximum of the youth. The study revealed that youth has become numb to chat in worshipping places, homes when relatives and guests are around, highways, schools, colleges and social gatherings. The study also points out the situation wherein youth are so inattentive and immersed into their phones that they do not even worry to look up as to where they are which results in their helplessness to prioritize as to what is important and what isn't. The study concluded that concentration has thus been altered from real to virtual world and visible to invisible friends. 


\section{OBJECTIVES OF THE STUDY}

- $\quad$ To analyse the impact of social networking sites among Women undergraduate students.

- $\quad$ To analyse the usage pattern of social networking sites among women undergraduate students.

- $\quad$ To identify the most preferred social networking sites among women undergraduate students.

\section{RESEARCH METHODOLOGY}

Sampling method used to conduct the study was convenience sampling method which is a non-probabilistic sampling technique. The study was conducted for a period of 3 weeks. The study is descriptive in nature. A descriptive survey seeks to find out some facts concerning in an existing phenomenon.

The area of the study is women undergraduate students in Coimbatore. The choice of the area was for proximity and to ensure effective distribution and collection of data through the use of a questionnaire were properly tabulated. The tabulated data have been properly analysed by using the statistical tool percentage analysis, mean score and ANOVA were used. The data necessary for the women undergraduate students has been collected from primary and secondary sources.

The population of this study comprises the entire women undergraduate Students. The sample size is 115 respondents of women undergraduate students. One hundred and fifteen copies of questionnaire were distributed to the respondent (women undergraduate students) by the researchers and were collected by the researcher to ensure an accurate return rate.

\section{DATA ANALYSIS AND INTERPRETATION \& RESULTS}

Table No: 1 Table showing demographic factors of respondents

\begin{tabular}{|l|l|l|l|}
\hline \multirow{2}{*}{$\begin{array}{l}\text { Are parents aware } \\
\text { of SNS activities }\end{array}$} & Yes & 85 & 73.9 \\
\cline { 2 - 5 } & No & 25 & 21.7 \\
\hline $\begin{array}{l}\text { SNS Technology } \\
\text { in College }\end{array}$ & Yes & 5 & 4.3 \\
\cline { 2 - 5 } & No & 115 & 100.0 \\
\hline $\begin{array}{l}\text { Effectiveness of } \\
\text { privacy policy }\end{array}$ & No & 65 & 56.5 \\
\hline
\end{tabular}

\begin{tabular}{|l|l|l|l|}
\hline \multicolumn{2}{|c|}{ Demographic Profile } & \multicolumn{1}{c|}{$\begin{array}{c}\text { No. of } \\
\text { Respond ents }\end{array}$} & Percentage \\
\hline \hline \multirow{2}{*}{ Age } & 18 & 45 & 39.1 \\
\cline { 2 - 4 } & 19 & 35 & 30.4 \\
\cline { 2 - 5 } & 20 & 35 & 30.4 \\
\hline \multirow{3}{*}{ Area } & Rural & 45 & 39.1 \\
\cline { 2 - 5 } & Urban & 70 & 60.9 \\
\hline \multirow{3}{*}{ Usage } & $1-5$ & 104 & 90.4 \\
\cline { 2 - 5 } & $6-10$ & 10 & 8.6 \\
\cline { 2 - 5 } & $10-15$ & 1 & 34.8 \\
\hline
\end{tabular}




\begin{tabular}{|l|l|l|l|}
\hline & & & \\
\hline $\begin{array}{l}\text { SNS Technology } \\
\text { in College }\end{array}$ & Nos & 115 & 100.0 \\
\cline { 2 - 4 } & No & & \\
\hline $\begin{array}{l}\text { Effectiveness } \\
\text { privacy policy }\end{array}$ & No & 65 & 56.5 \\
\cline { 2 - 4 }
\end{tabular}

\begin{tabular}{|c|c|c|c|}
\hline \multirow{2}{*}{$\begin{array}{l}\text { Do you thing } \\
\text { social networkin } \\
\text { sites important }\end{array}$} & Yes & 95 & 82.6 \\
\hline & No & 20 & 17.4 \\
\hline \multirow{4}{*}{$\begin{array}{l}\text { Social Networking } \\
\text { sites wher } \\
\text { respondents have } \\
\text { profile }\end{array}$} & Facebook & 30 & 26.1 \\
\hline & Whats app & 75 & 65.2 \\
\hline & Email & 5 & 4.3 \\
\hline & Intsagram & 5 & 4.3 \\
\hline \multirow{3}{*}{$\begin{array}{l}\text { How do you } \\
\text { access SNS }\end{array}$} & $\mathrm{PC}$ & 35 & 30.4 \\
\hline & Laptop & $p$ & 4.3 \\
\hline & Smartphone & 13 & 65.2 \\
\hline \multirow{3}{*}{$\begin{array}{l}\text { Time spent or } \\
\text { SNS }\end{array}$} & $1-2$ & 87 & 10.7 \\
\hline & $6-10$ & 14 & 12.2 \\
\hline & $10-15$ & 14 & 12.2 \\
\hline \multirow{3}{*}{$\begin{array}{lr}\text { Do you accep } \\
\text { strangers } \\
\text { friends }\end{array}$} & Yes & 45 & 39.1 \\
\hline & No & 55 & 47.8 \\
\hline & Sometimes & 15 & 13.0 \\
\hline
\end{tabular}

It is observed from the table that out of 115 respondents, 43 were 18 years of age, 35 were 19 years of age and 35 were 20 years of age. $39 \%$ of the respondents were from rural background and $61 \%$ of respondents were from urban background. $90 \%$ of the respondents have 1-5 accounts in Social networking sites and $34 \%$ of respondents use social networking sites to find information, $21 \%$ respondents use it to keep in touch with family, and $13 \%$ of respondents use it to make new information.

Out of 115 respondents, $82.6 \%$ think that social networking is important. $65 \%$ of the respondents have account in whatsapp, while $26 \%$ of respondents have account in facebook. $65 \%$ of respondents access social networking sites using smart phone. $76 \%$ of respondents spent 1-5 hours daily on SNS and $47 \%$ of respondents accept the strangers as friends. $74 \%$ of respondents opined that their parents are aware of their SNS activities. And all the respondents opined that SNS technologies are used in college campus. $57 \%$ of respondents opined that privacy policies are effective.

Table no: 2 Table Showing One Way ANOVA between area and impact of Social Networking Sites.

\begin{tabular}{|c|c|r|r|r|r|r|}
\hline \multirow{2}{*}{\multicolumn{2}{|c|}{ Impact }} & \multicolumn{5}{c|}{ Area } \\
\cline { 2 - 7 } & Sum of Squares & df & Mean Square & F & Sig. \\
\hline \multirow{3}{*}{$\begin{array}{c}\text { Positive } \\
\text { Impact }\end{array}$} & $\begin{array}{c}\text { Between } \\
\text { Groups }\end{array}$ & .715 & 1 & .715 & 7.608 & .007 \\
\cline { 2 - 7 } & Within Groups & 10.623 & 113 & .094 & & \\
\hline
\end{tabular}


Impact On Social Networking Sites Among The Women Undergraduate Students

\begin{tabular}{|c|r|r|r|r|r|r|}
\hline & Total & 114 & 11.338 & & & \\
\hline \multirow{4}{*}{$\begin{array}{c}\text { Negative } \\
\text { Impact }\end{array}$} & $\begin{array}{c}\text { Between } \\
\text { Groups }\end{array}$ & .687 & 1 & .687 & 10.459 & .002 \\
\cline { 2 - 7 } & Within Groups & 7.419 & 113 & .066 & & \\
\cline { 2 - 7 } & Total & 8.105 & 114 & & & \\
\hline
\end{tabular}

The above table indicates the Analysis of variance is done between familiarity area of residence and impact of Social Networking sites., The f value is 7.608 for positive impact and the significant value is 0.000 which is less than the acceptable value of 0.05 hence null hypotheses is rejected and it is inferred that area of residence does

influence the positive impact of Social Networking sites.The $\mathrm{f}$ value for negative impact is 10.459 and significance value is 0.002 which is less tha acceptable value of 0.05 , hence null hypothesis is rejected and is inferred that area of residence does influence the negative impact of social networking sites.

\section{Networking sites}

\begin{tabular}{|c|c|c|c|c|c|c|}
\hline \multirow{2}{*}{\multicolumn{2}{|c|}{ Impact }} & \multicolumn{5}{|c|}{ Familiarity } \\
\hline & & \multirow{2}{*}{$\begin{array}{r}\text { Sum of Squares } \\
1.638\end{array}$} & \multirow{2}{*}{ df } & \multirow{2}{*}{$\begin{array}{r}\text { Mean Square } \\
.819\end{array}$} & \multirow{2}{*}{$\begin{array}{l}\mathrm{F} \\
9.457\end{array}$} & \multirow{2}{*}{$\begin{array}{l}\text { Sig. } \\
\quad 000\end{array}$} \\
\hline \multirow{3}{*}{$\begin{array}{l}\text { Positive } \\
\text { Impact }\end{array}$} & $\begin{array}{l}\text { Between } \\
\text { Groups }\end{array}$ & & & & & \\
\hline & Within Groups & 9.700 & 112 & .087 & & \\
\hline & Total & 11.338 & 114 & & & \\
\hline \multirow{3}{*}{$\begin{array}{l}\text { Negative } \\
\text { Impact }\end{array}$} & $\begin{array}{l}\text { Between } \\
\text { Groups }\end{array}$ & 1.098 & 2 & .549 & 8.775 & .000 \\
\hline & Within Groups & 7.007 & 112 & .063 & & \\
\hline & Total & 8.105 & 114 & & & \\
\hline
\end{tabular}

The above table indicates the Analysis of variance is done between familiarity of Social Networking sites and impact of Social Networking sites., The f value is 9.457 and the significant value is 0.000 which is less than the acceptable value of 0.05 hence null hypotheses is rejected and it is inferred that familiarity of SNS does influence the impact of

Table No: 4 Table showing Mean Score of positive impact variables of Social Networking Sites

\begin{tabular}{|c|c|c|c|c|c|}
\hline \multirow{2}{*}{ Positive Impact } & \multirow[b]{2}{*}{$\mathrm{N}$} & \multirow{2}{*}{ Mini } & \multirow[b]{2}{*}{ Max } & \multirow[b]{2}{*}{ Mean } & \multirow[b]{2}{*}{ STD } \\
\hline & & & & & \\
\hline $\begin{array}{l}\text { Social Networking have impact on Character } \\
\text { formation of Youth }\end{array}$ & 115 & 1.00 & 5.00 & 4.43 & .496 \\
\hline $\begin{array}{l}\text { Social Networking sites provide a platform to } \\
\text { express opinions and views on current Issues }\end{array}$ & 115 & 1.00 & 5.00 & 4.46 & .629 \\
\hline $\begin{array}{l}\text { Social Networking sites develop attitude of } \\
\text { youth }\end{array}$ & 115 & 1.00 & 5.00 & 4.16 & .496 \\
\hline $\begin{array}{l}\text { Social Networking sites increases knowledge } \\
\text { of youth }\end{array}$ & 115 & 1.00 & 5.00 & 4.45 & .629 \\
\hline $\begin{array}{l}\text { Social Networking sites facilitates } \\
\text { opportunity for learning and work }\end{array}$ & 115 & 1.00 & 5.00 & 4.39 & .507 \\
\hline Total Mean & & & & 4.38 & \\
\hline
\end{tabular}

Social Networking sites. The f value for negative impact is 8.775 and significance value is 0.000 which is less than acceptable value of 0.05 , hence null hypothesis is rejected and is inferred that familiarity of SNS does influence the negative impact of social networking sites. 
The above table shows the respondents' level of agreeability towards positive impact of usage of social networking sites; the agreeability is high towards the Social Networking sites provide a platform to express opinions and views on current Issues (4.46) and low towards Social Networking sites develop attitude of youth (4.16).

Total mean is 4.38 , which is observed as the respondents agreed that there is positive impact in using social networking sites.

Table No:5 Table showing Mean Score of negative impact variables of Social Networking Sites

\begin{tabular}{|c|c|c|c|c|c|}
\hline \multirow{2}{*}{ Negative Impact } & \multirow[b]{2}{*}{$\mathrm{N}$} & \multirow[b]{2}{*}{ Mini } & \multirow[b]{2}{*}{ Max } & \multirow[b]{2}{*}{ Mean } & \multirow[b]{2}{*}{ STD } \\
\hline & & & & & \\
\hline $\begin{array}{l}\text { Youth waste a lot of time in front of social } \\
\text { networking sites }\end{array}$ & 115 & 1.00 & 5.00 & 4.01 & .63306 \\
\hline Social Networking increases Cyber crime & 115 & 1.00 & 5.00 & 4.05 & .45583 \\
\hline $\begin{array}{l}\text { Social networking sites may cause people to } \\
\text { lose track and time and severely addicted to } \\
\text { use }\end{array}$ & 115 & 1.00 & 5.00 & 4.29 & .56154 \\
\hline $\begin{array}{l}\text { Social Networking sites can be served as an } \\
\text { avenue for predators to find victims }\end{array}$ & 115 & 1.00 & 5.00 & 4.35 & .71382 \\
\hline Total Mean & & & & 4.18 & \\
\hline
\end{tabular}

The above table shows the respondents' level of agreeability towards negative impact of usage of social networking sites; the agreeability is high towards the Social Networking sites can be served as an avenue for predators to find victims (4.35) and low towards Youth waste a lot of time in front of social networking sites (4.01).

Total mean is 4.18 , which is observed as the respondents agreed that there is negative impact in using social networking sites.

\section{CONCLUSION}

From the analysis it is found that respondents use social networking sites to gather new information and to keep in touch with family and friends. Majority of the respondents also perceive that social networking sites are important. The ANOVA analysis revealed that the familiarity of using SNS and Area of residence does influence the impact of using social networking sites. The majority of the respondents who spends varying amount of time less than one hour to five hours per day in social networking sites. Women Students with heavy users can moderate their usage of various sites to avoid the addiction with some specific sites.

\section{REFERENCES}

1. Awake, (2011, July). What Should I know social networking? Part 1, pp. 24.25.

2. Baker, Adam. (October, 2009). Phishing Scams Continue to Plague Social Media Sites. Wise Bread. Retrieved April 22, 2011, from World Wide Web. http://www.wisebread.comphishing-scams-continue-toplague-social-media-sites.

3. Bharadwaj, Akashdeep (2017), International Journal for Electronics and electronic engineering, 7(1),pp.41-51

4. Boyd, D.M., Ellison B.N. (2007), Social Networking Sites: definition of history and scholarship: journal of computer -mediated Communication, 13(1) (2007), pp. 210-230.
5. Coleman, S. \& Rowe, C. (2005). Remixing Citizenship: Democracy and young people's use of the internet a report for the carnegre young people's initiative.

6. Deshmukh and Tathe (2014).An impact of Social Networking Sites on Youngsters. ational Journal of Management (IJM), Vol. 5, Issue 12. ISSN 0976- 6502 (Print) ISSN 0976-6510 (Online)

7. Ellison, N.B.. (2007), Benefits of Facebook 'friends': Social capital and College Students' use of Online Social Network Sites: Journal of Computer-mediated communication, 12(4) (2007).

8. Fisher, Dennis. (May, 2011) Phishing, Social Networking Attacks on the Rise. Threat Post. Retrieved July 11, 2011, from World Wide Web. http://threatpost.com/enUS/blogsPhishing-socialnetworking-attack-rise-05/2011.

9. Hartup, W.W. \& Stevens, N. (1999). Friendships and Adaption Across the life span. In Current Direction in Psychological Science 8(3): 76-79.

10. Karidakis, P. \& Hanson, G. (2009). "Social Interaction and Co-Viewing with youtube: blending Mass Communication reception and social connection". Journal of Broadcasting and electronic Media, pp. 317 335.

11. Khurana, N.(2015) Journal of Mass communication and journalism 5(12), pp.1-4

12. Muhammad, Abdullah and Azmi(2016). The Negative Impact of Technology on Social Networking among Students at UTM students Skudai. Nova Journal of Engineering and Applied Sciences Vol. 5(1), DOI: 10.20286/nova-jeas-050102

13. Neelamalar and Chitra(2009). New Media and Society: A Study of Social Networking Sites on Indian Youth. Department of Defense's advanced Research Project Agency.

14. Subramani. R (2015), Online Journal of Communication and Media Technologies, 5(3), pp.162-175. 
15. Valkernburg, P.M., Peter, J., \& Schouten, A.P. (2006), Friend networking sites and their relationship to adolescent wellbeing.

16. Zeller, Bill (September 2008). Popular Websites Vulnerable to Cross-Site Request forgery Attacks. Retrieved April 27, 2008. from World Wide Web: http://www.freedom.totinker.com/blog/wzeller-popularwebsite-vulnerable./cross.site.reals. 